\title{
Effect of Different Concentration of Ri Plasmid on Division of Electrotreated Cell Suspension Culture derived from Stem Callus of Vicia faba L. Plants Embedded in Agar Multiple Drops
}

\author{
${ }^{1 *}$ Sahla M. Zedan, ${ }^{2}$ Mozahim K. Al-Malah \\ ${ }^{1 *}, 2$ Department of Biology, College of Education for Pure Science, University of Mosul, Mosul, Iraq \\ E. Mail ${ }^{1^{*}}$ dr.sahla1953@uomosul.edu.iq, ${ }^{2}$ mozahim.k@ huc.edu.iq
}

(Received April 12, 2021; Accepted June 07, 2021; Available online August 28, 2021)

DOI: 10.33899/edusj.2021.168834, (c) 2021, College of Education for Pure Science, University of Mosul.

This is an open access article under the CC BY 4.0 license (http://creativecommons.org/licenses/by/4.0/).

\begin{abstract}
Samples of cell suspension represents seven different densities were exposed to three electrotreatment 40, 50,60 volt and for a period of time 50, $100 \mathrm{msec}$ then the densities were mixed with different concentration of Ri plasmid 25, 50, 75 Microliter. The electrotreatment samples cultured by embedding in to agar drops in solid-liquid cultures.

Results proved that the electrotreatment enhanced division of cell suspension and caused a clear increase of microcolonies, the total number of colonies reached 3276 when suspension culture was exposed to 50v / 100 msec., these colonies developed to microcalli and the percentage was 90\%. The Callus developed from these colonies was light green in color and friable in texture.
\end{abstract}

Keywords: Vicia faba, cell suspension, cocultivation, Agrobacterium rhizogenes.

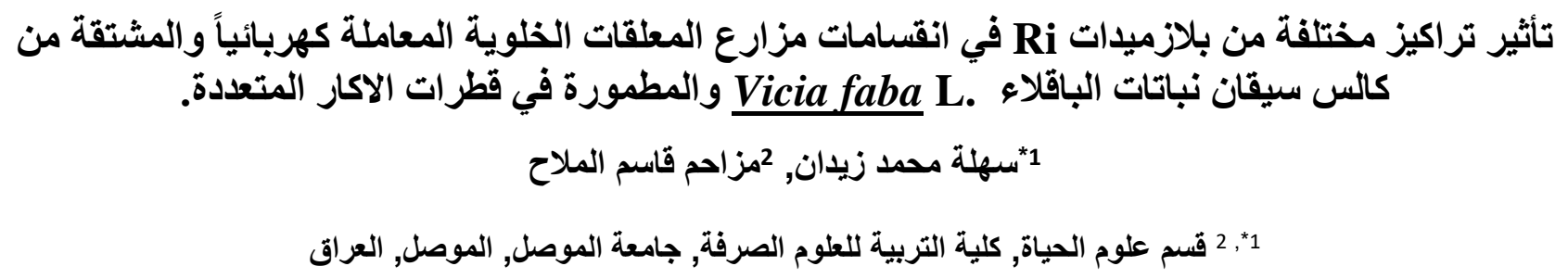

الخلاصة

عرضت مجموعة عينات من مزارع المعلقات الخلوية تمثل سبعة كثافات متباينة الى ثلاثة معاملات كهربائية 40، 50، 60

فولت ولفترات زمنية امدها 50، 100 ملي ثانية ثم مزجت هذه الكثافات المختلفة مع تراكيز مختلفة من بلازميد 25 Ri، 50، 75

مايكروليتر • زرعت هذه العينات بطمرها في قطرات الاكار باعتماد المزارع الصلبة - السائلة وبرهنت نتائج هذه المزارع تشجيع انقسامات

الخلايا المفردة وتكوين اعداد كبيرة من المستعمرات الخلوية بلغ أقصاها 3276 مستعمرة عند تعريض مزارع المعلقات الخلوية للمعاملة 


\section{Journal of Education and Science (ISSN 1812-125X), Vol: 30, No: 3, 2021 (225-235)}

Special Issue for Proceeding of $3^{\text {rd }}$ National (1st international conference of biology) (ICBSUM 2021) 5, 6 July

College of Education for Pure Science, University of Mosul, Mosul, Iraq.

الكهربائية كهربائية .50V/100 msec. وتطورت هذه المستعمرات الى بادئات الكالس، اذ بلغت نسبتها 90\%، واتصف الكالس المتكون في القطرات بلونه الأخضر الفاتح قوامه الهش.

الكلمات المفتاحية: Vicia faba, cell suspension, cocultivation, Agrobacterium rhizogenes

\section{المقدمة}

تنتمي نباتات الباقلاء Vicia faba Labaceae الى العائلة البقولية ضمن الفصيلة الفراشية Papilionaceae (1) • وتضم هذه العائلة حوالي 625 جنساً و 1800 نوع، وتعد احدى العوائل النباتية المهمة اقتصادياً فهي تضم بقوليات حبوب Grain legume غنية بالبروتين تمثل مصدراً لغذاء الانسان واخرى علفية Forage Legume تمثل مصدراً لتغذية الحيوان (2). ويضم الجنس Vicia انواعاً كثيرة يزرع منها في العالم 76 نوعاً لأغراض اقتصادية.

تعد المزارع الصلبة السائلة نظاماً جيداً لدراسة نمو خلايا النبات وتخصصها وهي تتكون من خلايا مفردة أو كتل صغيرة من Medicago sativa الخلايا في وسط غذائي سائل متثابهة إلى حد ما فسلجياً وحيوياً. وقد اوضحت دراسة زراعة بروتوبلاست الجت وهات باتباع تقنية قطرات الاكار ان الخلايا بدأت بالانقسام خلال 72 ساعة من الزراعة وباشرت انقسامها الثاني بعد 48 ساعة من حدوث الانقسام الاول وابتدأ تكوين المستعمرات الخلوية خلال 7 ايام من الزراعة وأمكن مشاهدتها بوضوح بالمجهر الضوئي بعد 14-21 يوماً من الزراعة، وظهرت قطع الكالس في القطرات خلال اربعة اسابيع من الزراعة(3).

كما وأوضحت بعض الدراسات ان للمعاملة الكهربائية دوراً بارزاً في تثجيع انقسام خلايا المعلقات الخلوية لعدد من نباتات ذوات الفلقتين والفلقة الواحدة ـ فقد اشارت احدى هذه الدراسات إلى ان عمليات التثيب الكهربائي Electroporation شجعت على نحو واضح Pennisetum squamulatum انقسام خلايا المعلقات الخلوية للبروتوبلاست وتلك المشتقة من الكالس في نباتات ذوات الفلقة الواحدة ولوحظ ان حيوية هذه الخلايا تراوحت بين 90-95\% وبدأت عملية تشكيل الجدار ومباشرة الانقسامات الخلوية مبكراً خلال 4 ايام من الزراعة مقارنة بنظيراتها غير المعاملة التي استلزمت 7 ايام مع استمرارها بالانقسام وتكوين المستععرات الخلوية وتطورها الى منشأت

كما ان منظمات النمو المضافة الى المزارع الصلبة السائلة تشجع انقسام الخلايا وتكوين المستعمرات الخلوية من خلال تأثيرها في زيادة بناء DNA في البروتوبلاست المعزول مما يؤدي الى زيادة معدل الانقسامات الخلوية المتتالية وتكوين المستعمرات الخلوية

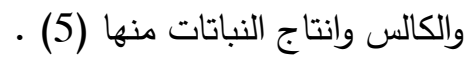

فقد استغلت قدرة البكتربيا (Agrobactirum rhizogenes) على تداخلها وتوافقها مع عدد من الانواع النباتية باستخدامها بوصفها نواقل طبيعية في عملية التحول الوراثي للنباتات. وخلال هذه العملية تتتقل قطعة من DNA البلازميد البكتيري تدعى T-DNA الى خلايا النبات العائل وتتدمج مع تركييها الوراثي (6) ـ ان هذه القطعة تحتوي على عدد من الجينات التي يعبر عنها Gene expression عند انتقالها في النبات العائل كما توجد جينات اخرى في مواقع أخرى من البلازميد تدعى Virulence genes وظيفتها نقل قطعة T-DNA 


\section{Journal of Education and Science (ISSN 1812-125X), Vol: 30, No: 3, 2021 (225-235)}

Special Issue for Proceeding of $3^{\text {rd }}$ National (1st international conference of biology) (ICBSUM 2021) 5, 6 July

College of Education for Pure Science, University of Mosul, Mosul, Iraq.

من البكتريا الى النبات ويعبر عنها في ظروف توافق معينة وبوجود مواد فينولية تحررها مجموعة من خلايا النبات في منطقة الجرح او

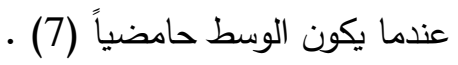

تهدف الدراسة الحالية الى تطبيق تقنية الزراعة المرافقة Cocultivation لمزيج المعلقات الخلوية وبلازميدات Ri المعزولة من بكتريا A.rhizogenes من خلال تحقيق ما ياتي :

$$
\text { Ri أ- عزل بلازميدات }
$$

ب- التعرف على دور المعاملة الكهربائية Electroporation في انقسامات المعلقات الخلوية وتكوين بادئات الكالس بوجود بلازميد

تم الحصول على بذور الباقلاء .Vicia faba (الصنف المحلي) من مركز البحوث الزراعية في نينوى.

عقدت بذور الباقلاء بغدها في الكحول الاثيلي تركيز 96\% مع التحريك المستمر مدة دقيقتين متبوعاً بغرها في محلول القاصر التجاري هايبوكلورايت الصوديوم NaOCI بنسبة 1 حجم قاصر : 2 حجم ماء مدة 30 دقيقة ـ. رفعت البذور وغسلت جيداً بالماء المعقم اربع مرات متتالية (5 دقائق / مرة) لإزالة اثار المادة المعقدة (8).

زرعت بذور الباقلاء المعقمة سطحياً بعد ازالة غلافها على سطح 20 مل من وسط MS (9) الصلب الخالي من منظمات النمو في أنابيب اختبار بحجم 70 مل بواقع بذرة واحدة ـ حفظت العينات في غرفة الزرع (Culture room) في الظلام التام للايام الثلاثة الاولى منى وبدرجة حرارة 25 25 20 حتى ظهور الجذير وبداية الرويشة ـ بعدئذ نقلت البادرات الناتجة الى ظروف الضوء والظلام المتعاقب (16 ساعة ضوء /8 ساعة ظلام) ، وبشدة اضاءة 2000 لوكس حتى اكتمال تكوين البادرات اللازمة .

\section{استحداث الكالس من الاجزاء النباتية}

استخدمت البادرات الناتجة بعمر اربعة اسابيع مصدراً لقطع السيقان لاستحداث الكالس منها على وسط MS الحاوي على 1.0 ملغم /

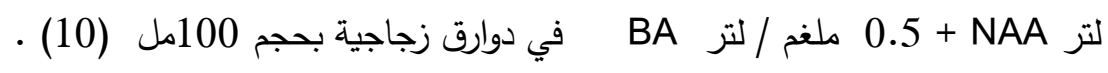
انشاء مزارع المعلقات الخلوية من الكالس

اتبعت الطريقة القياسية المعتمدة (11) في انثاء المعلقات الخلوية المشتقة من الكالس. أخذ 1غم من كالس السيقان الفتي الهش وبعدر 3 اسابيع ويوضع في دوارق زجاجية سعة 250 مل يحتوي كل منها على 50 مل من وسط MS . حضنت هذه المزارع في الكزازة

في ظروف ظلام تامة وبدرجة حرارة 28 مج وسرعة دورانية 150 دورة /دقيقة . وبعد مضي 24 ساعة تزال المزرعة وترشح من خلص منخل بلاستيكي معقم دقيق بحجم Plant Genetic Manipulation. U.K) 46 Dm لازالة الكتل الخلوية

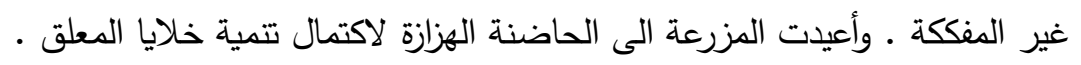




\section{تحديد كثافة المعلقات الخلوية}

اخذت عينات بحجم 0.1 مل من مزرعة المعلقات الخلوية بعد مضي 24 ، 48 ، 72 ساعة من التحضين ووضعت على شريحة

$$
\text { تقدير حيوية خلايا المعلقات الخلوية الهيموسايتويتر للتعرف على نمو الخلايا و تزايد اعدادها مع عمر المزرعة (12 ). }
$$

اعتمدت طريقة تقدير حيوية البروتوبلاست (10) باستخدام محلول صبغة Evansblue المحضرة باذابة 0.5 غرام في 100

سم3 من الماء المقطر تم مزج محلول الصبغة بمحلول المانيتول بمقدار 3 غم/لتر ـ اخذ 1 مل من المعلق الخلوي ومزج مع 1 مل من محلول الصبغة. ووضع على شريحة Hemocytometer . حسب العدد الكلي للخلايا وكذلك عدد الخلايا الحية للتعرف على نسبة حيوية الخلايا. مصدر سلالة البكتريا

Professor E. W. Nester. من جامعة واشنطن Agrobacterium rhizogenes من بكتريا R1601 تحصول على السلالة - (Washington. Univ. U.S.A

\section{APM تحضيروسط}

حضر هذا الوسط باذابة مكوناته جيداً في حجم مناسب في الماء المقطر ، أضيف إلى الوسط 100ملغرام/تتر من كل من المضادين الكانامايسين والكاربنسلين وصلب باضافة 15 غم/لتر من الاكار وضبط الرقم الهيدروجيني بحدود 6.6 ـ

$$
\text { Ri عزل البلازميدات }
$$

استخدمت طريقة (13) لعزل الـDNA البلازميدي وحددت كثافة المعلق البكتيري عند قراءتها طيفياً.

تعربض مزارع المعلقات الخلوية المشتقة من كالس السيقان للمعاملة الكهربائية

اخذت حجوم معينة من كثافات مختلفة ـ من مزارع المعلقات الخلوية النامية في وسط MS السائل ووضعت في حجرة جهاز التثقيب الكهربائي المعقدة ـ بعدئذ ربطت الحجرة إلى اقطاب الجهاز و انتخبت ثلاث فولتيات 60,50,40 فولت و لفترات زمنية امدها 50, 100 ملي ثانية (14)

\section{Ri مرافقة المعلق الخلوي مع بلازميدات}

مزج المعلق الخلوي المشتق من الكالس الهش وبكثافات مختلفة والنامي في الوسط السائل (MS) + NAA 1.0 ملغرام/لتر 0.5 + NAA ملغرام/لنر BA مع بلازميد Ri وقد اختبرت تراكيز البلازميد 25 ، 50 ، 75 مايكروليتر وبكثافة 35.355 ملغرام/مل. 
زراعة المعلقات الخلوية المعاملة كهربائيا والمرافقة ببلازميدات

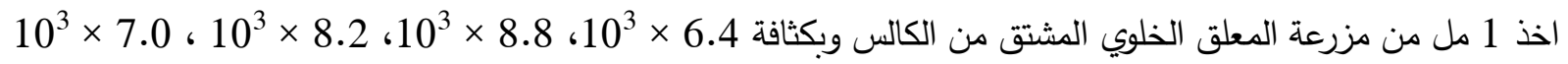
، 4.9 × 25 مايكروليتر من بلازميد Ri وبعد مزجهما مباشرة اخذ هذا المزيج واضيف اليه 1 مل من 3\% من محلول الاكار المعقم السائل بدرجة حرارة 45 ج • وزع المزيج بصورة قطرات متماثلة الحجم باستخدام ماصة معقمة حجم 1 مل وضعت في قعر اطباق بتري البلاستيكية قطر 9 سم على هيئة قطرات مركزية واخرى محيطية يتراوح مجموعها 20 قطرة /طبق تركت الاطباق لكي تجف في كابينة الزرع ، اضيف إلى القطرات بعد تصلبها 3 مل من الوسط السائل نفسه ، غلقت الاطباق وتركت في ظروف غرفة الزرع المذكورة سابقا .

ادامة مزارع قطرات الاكار المتعددة وإتحداث الكالس

تمت ادامة مزارع قطرات الاكار المتعددة ولكافة المعاملات المستخدمة كل اربعة ايام وذلك بسحب الوسط القديم باستخدام ماصة معقمة (Quick Pette-F) حجم 1 مل والتعويض عنه بنفس الكمية من الوسط السائل الجديد المعقم ذاته مع تحريك الطبق بهدوء ليتم انتشار الوسط السائل في الطبق كله مع مراعاة عدم غمر القطرات بالوسط ، ان تجديد الوسط يثجع انقسام الخلايا واستمرارها بالنمو - بالم

زراعة المعلقات الخلوية المعاملة كهربائيا والمرافقة ببلازميد Ri بتركيز 25 مايكروليتر اظهرت نتائج زراعة كثافات مختلفة 6.4 × $10^{3}$ ، 8.8 × $10^{3}$ ، 8.2 × 7.0 × $70^{3}$ ، 4.9 × $10^{3}$ ×ن المعلقات الخلوية Ri التي تراوحت حيويتها بين 83-91\% المعرضة مسبقا للمعاملة الكهربائية والمحضنة كل منها بعدئذ مع 25 مايكروليتر من بلازميد في الوسط الصلب (MS + NAA + 1.0 ملغرام/لتر 0.5 ملغرام/لتز BA بتقانة قطرات الاكار المتعددة انها شجعت انقسامات خلايا المزرعة ـ فقد بدأت الخلايا المعرضة انقسامها الاول عند اليوم الرابع من زراعتها ودخلت هذه الخلايا المنقسمة انقسامها الثاني بعد 48 ساعة من حدوث الانقسام الأول (الثكل a.1) وواصلت الخلايا المنقسمة تكوينها مرحلتي ثلاثية ورباعية الخلايا خلال الاسبوع الاول من زراعتها (الثكل 1b.1) وظهرت اولى المستعمرات الخلوية بعد 14-25 يوما من الزراعة (الثكل c.1). ومن النتائج المميزة لهذه المعاملة انها شجعت تكوين اعداد كبيرة من المستعمرات خلال 21 يوما منتجة منشأت الكالس بهيأة كتل صغيرة الحجم بيضاء اللون أمكن ملاحظتها بالعين (الثكل 1.1) تمكنت خلال مدة 14 يوما مع استمرار ادامتها من النمو والزيادة في الحجم إلى قطع صغيرة من الكالس (الثكل (e.1). ان تعريض المعلقات الخلوية للمعاملة بـ 50V/50msec والمعاملة 50V/100msec والمحضنة مع 25 مايكروليتر شجعت حصول زيادة في اعداد المستعمرات الخلوية المتكونة اذ بلخ اقصاها 3012 مستعمرة وادى نشوء 480 بادئة كالس، لقد بلغت نسبة تكوين منشأت الكالس في المعاملتين اقصاها 87\% عند اقصى كثافة مستخدمة قياسا إلى عينة المقارنة اذ بلغت نسبة تكوينها 69\% (الجدول 1) اما المعاملات 60V و 60V/100msec و و60V/100msec فقد شجعت زيادة في اعداد المستعمرات الخلوية ولكن بنسبة 
Journal of Education and Science (ISSN 1812-125X), Vol: 30, No: 3, 2021 (225-235)

Special Issue for Proceeding of $3^{\text {rd }}$ National (1 $1^{\text {st }}$ international conference of biology) (ICBSUM 2021) 5, 6 July

College of Education for Pure Science, University of Mosul, Mosul, Iraq.

اقل من المعاملتين السابقتين وبلغت نسبة تكوين الكالس فيهما 80\% و 80\% و 78\% على التوالي (الجدول 1) . . وتمكنت خلايا المعق الخلوي غير المعاملة كهربائيا من دون اضافة البلازميد من تكوين منشأت الكالس بعد 90 يوما في حين لوحظ في مزرعة المعلقات الخلوية المعرضة للمعاملة 50V/50msec وبوجود البلازميد تفوقها في اعداد منشأت الكالس المتكونة واتصف الكالس بلونه الاخضر الفاتح (الثكل 1 f.1) وتكونه بعد 50 يوما من الزراعة وادت عملية تعريض المعلق الخلوي للمعاملة 50V/100msec إلى تبكيرها في تكون الكالس مع انخفاض يعتبر بسيط في اعداد المنشأت المتكونة ـ واظهرت المعاملة 40V/100msec تاثيرا مماثلا في خفض اعداد المنشأت المتكونة على الرغم من التبكير في تكوينها. وعند استخدام الفولتية 60V في تعريض المعلقات الخلوية مع تباين مدة التعريض 50V/100msec اظهرت تاثيرا متناظرا في احداث انخفاض في اعداد المنشأت المتكونة قياسا إلى المعاملات الاخرى ولكنها تفوقت عن معاملة المقارنة

الجدول (1) : تكوين الكالس من زراعة المعلقات الخلوية المعاملة كهربائيا والمضاف اليها 25 مايكروليتر من بلازميدات Ri في وسط MS الصلب المدعم 1.0 ملغرام/لتر NAA + 0.5 ملغرام/تتر مA بتقانة قطرات الاكار المتعددة .

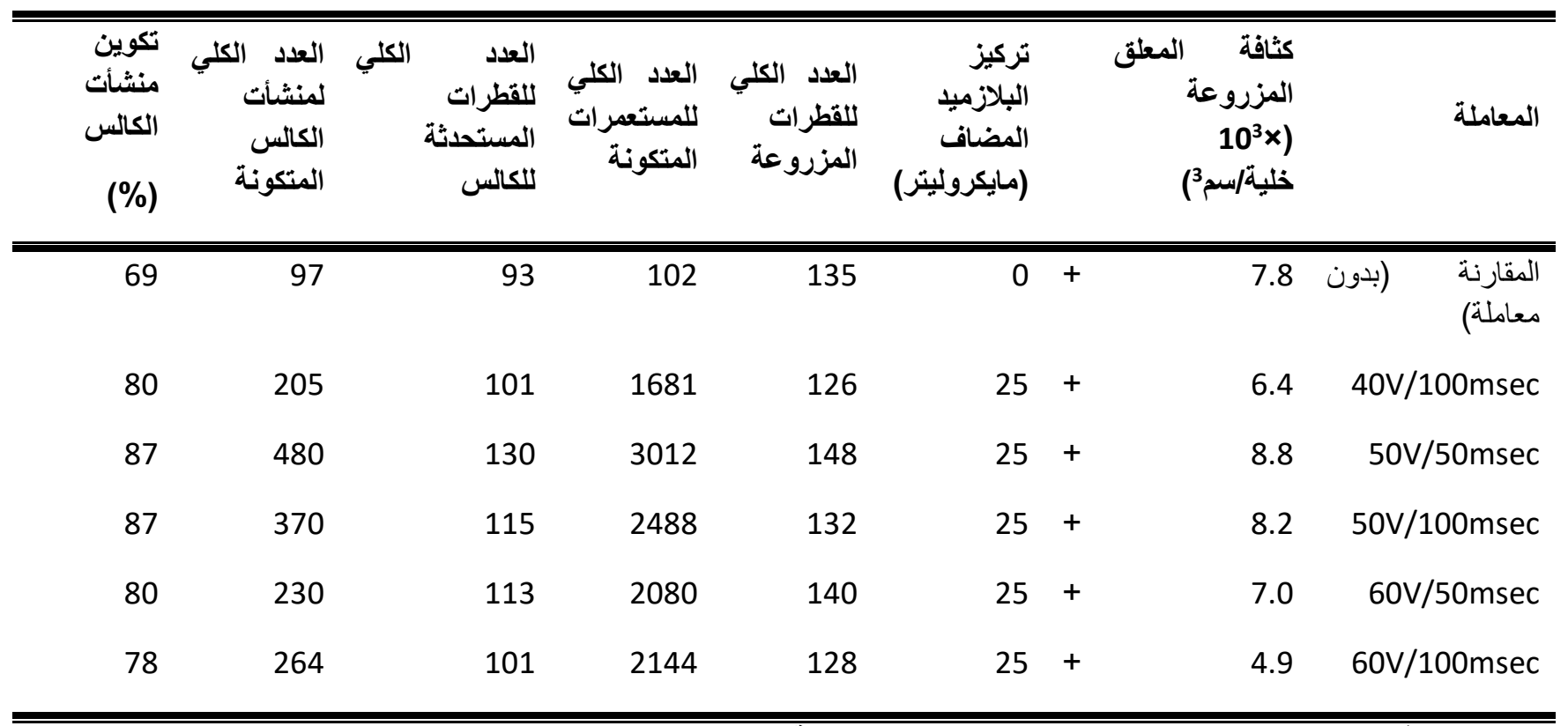

القيم الواردة في الجدول تمثل مكررات معدلات اربع مكررات لكل معاملة . 


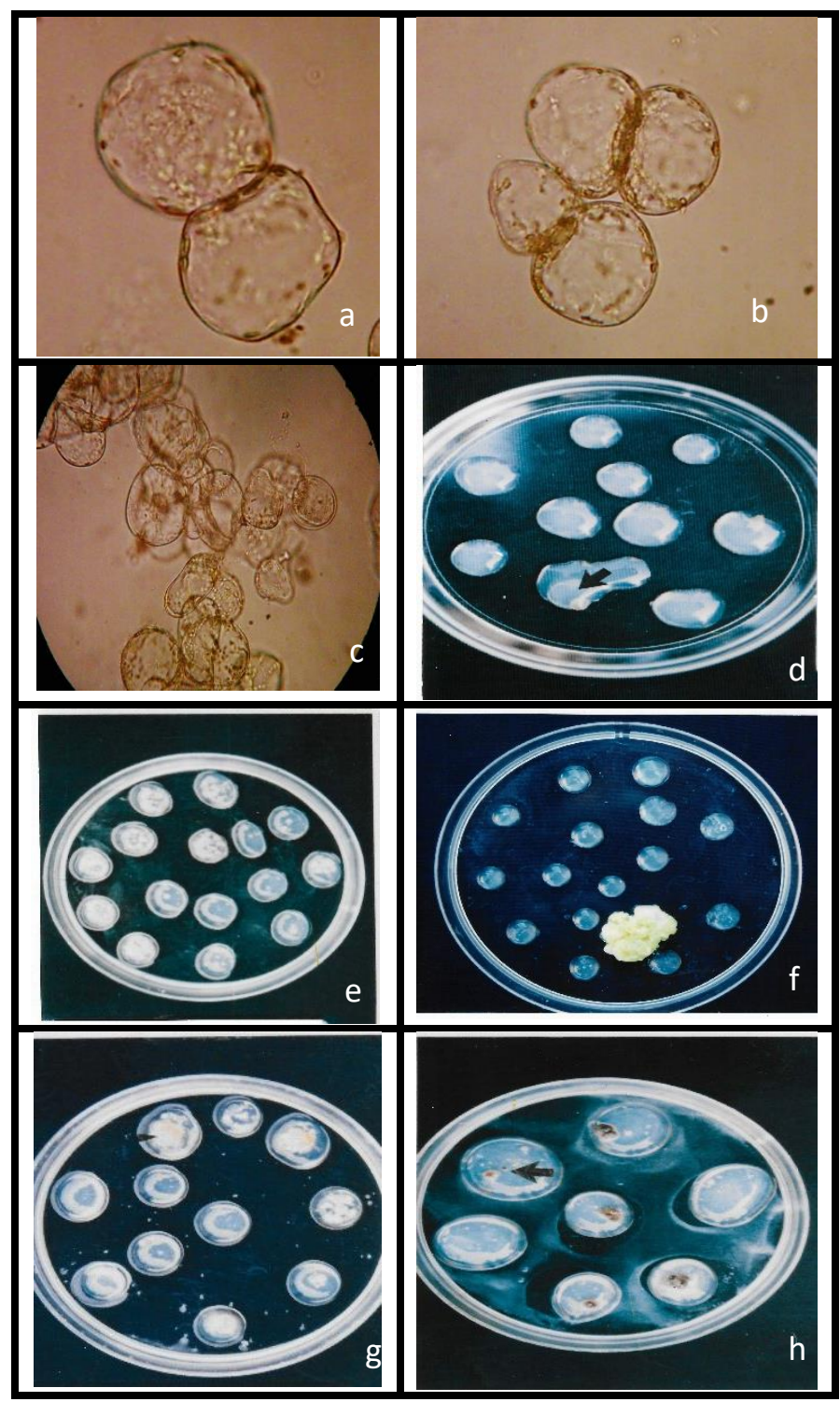

شكل (1): تكوين بادئات الكالس من المعلقات الخلوية المشتقة من كالس سيقان نباتات الباقلاء Vicia faba

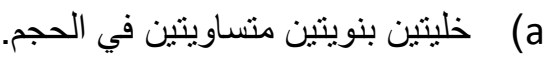

$$
\begin{aligned}
& \text { b الخلايا الرباعية. } \\
& \text { ) المستعمر ات الخلوية. (c } \\
& \text { بادئات كالس بيضاء اللون. (d ) (d }
\end{aligned}
$$

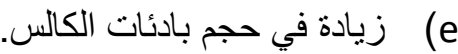

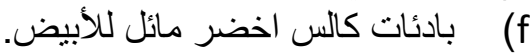

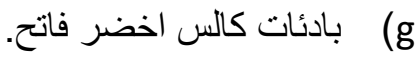

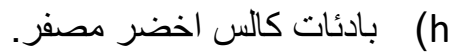


Journal of Education and Science (ISSN 1812-125X), Vol: 30, No: 3, 2021 (225-235)

Special Issue for Proceeding of $3^{\text {rd }}$ National (1 $1^{\text {st }}$ international conference of biology) (ICBSUM 2021) 5, 6 July

College of Education for Pure Science, University of Mosul, Mosul, Iraq.

\section{بوجود بلازميد Ri بتركيز 50 مايكروليتر}

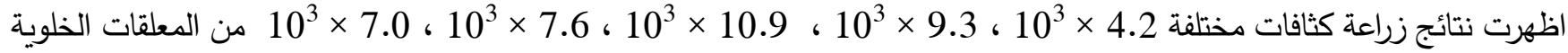
وكانت حيويتها 80\% ، 92\% ، 90\% ، 90\% ، 88\% على التوالي التي سبقت معاملتها كهربائيا لددد مختلفة 50 ، 100 ملي ثانية اعقبها تحضينها مع بلازميد Ri بتركيز 50 مايكروليتر استجابة مزارع المعلقات الخلوية للانقسام فقد بدأت جميع العينات للمعاملات كافة مباشرتها بالانقسام الاول بعد 4 ايام من الزراعة اعبهها دخول تلك الخلايا انقسامها الثاني بعد 48 ساعة من حدوث الانقسام الاول كما تكونت المرحلتان ثلاثية ورباعية الخلايا بعد مرور 7 ايام على الزراعة ـ وتمكنت الخلايا المنقسمة من مواصلة انقساماتها المتتالية التي نشأ عنها تكوين المستعمرات الخلوية الصغيرة خلال مدة 14-21 يوما من بدء الزراعة. ان تعريض مزارع المعلقات الخلوية للمعاملة 50V/100msec كان لها تأثير مشجع في تكوين اعداد كبيرة من المستعمرات الخلوية ومنشأت الكالس اذ بلغ العدد الكلي للمستعمرات الخلوية 3276 مستعمرة ومنشأت الكالس 510 أي بنسبة 90\% قياسا بعينة المقارنة اذ بلغ العدد الكلي للمستعمرات 90 مستعمرة فضلا عن تكوين 78 بادئة أي بنسبة 69\% (الجدول 2) ـ لقد تطورت هذه المستعرات في عينة الدقارنة ونتج عنها بعد 90 يوما من بدء الزراعة حتى صار بالامكان رؤيتها بالعين المجردة. كما اظهرت مزارع المعلقات الخلوية المعاملة كهربائيا بفولتية 50 فولت لمدتين زمنيتين 50 ملي ثانية و100 ملي ثانية والمضاف اليهما 50 مايكروليتر من بلازميد Ri والمزروعة بتقانة قطرات الاكار تحفيزا متناظرا في اعداد

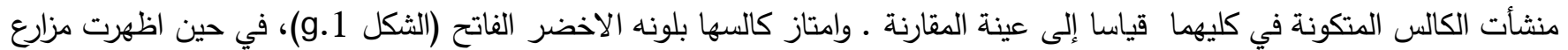

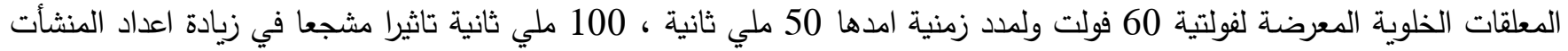

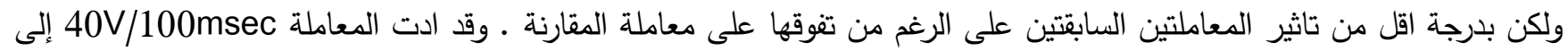

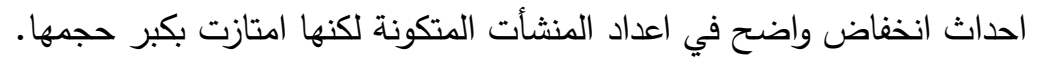

الجدول (2) : تكوين الكالس من زراعة المعلقات الخلوية المعاملة كهبائيا والمضاف اليها 50 مايكروليتر من بلازميدات Ri في وسط

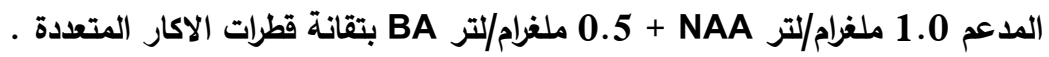

\begin{tabular}{|c|c|c|c|c|c|c|c|c|c|}
\hline 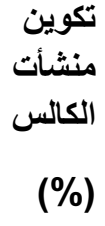 & الكنشأت الكلي & الكلي & اللقطرات & اللمستعمرات الكلي & اللقطرات الكلي & البلازميا & & كثزافة 1 المعلق & 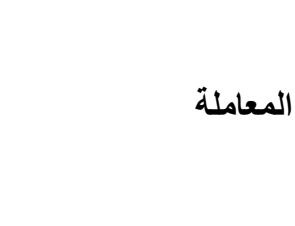 \\
\hline 69 & 78 & & 86 & 90 & 124 & 0 & + & 7.0 & المقارنة (بدون معاملة) \\
\hline 76 & 250 & & 87 & 2080 & 115 & 50 & + & 4.2 & $40 \mathrm{~V} / 100 \mathrm{msec}$ \\
\hline 89 & 430 & & 109 & 3032 & 122 & 50 & + & 9.3 & $50 \mathrm{~V} / 50 \mathrm{msec}$ \\
\hline 90 & 510 & & 101 & 3276 & 112 & 50 & + & 10.9 & $50 \mathrm{~V} / 100 \mathrm{msec}$ \\
\hline 84 & 360 & & 118 & 2850 & 118 & 50 & + & 7.6 & $60 \mathrm{~V} / 50 \mathrm{msec}$ \\
\hline 82 & 320 & & 103 & 2520 & 103 & 50 & + & 7.0 & $60 \mathrm{~V} / 100 \mathrm{msec}$ \\
\hline
\end{tabular}

القيم الواردة في الجدول تمثل مكررات معلات اربع مكررات لكل معاملة . 
Journal of Education and Science (ISSN 1812-125X), Vol: 30, No: 3, 2021 (225-235)

Special Issue for Proceeding of $3^{\text {rd }}$ National (1 $1^{\text {st }}$ international conference of biology) (ICBSUM 2021) 5, 6 July

College of Education for Pure Science, University of Mosul, Mosul, Iraq.

بوجود بلازميد Ri بتركيز 75 مايكروليتر

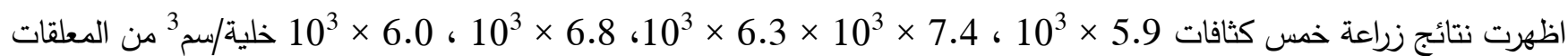

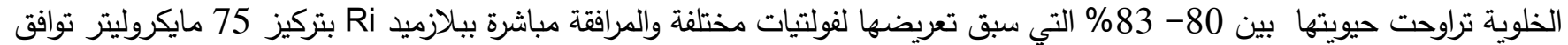

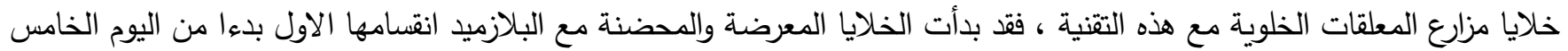

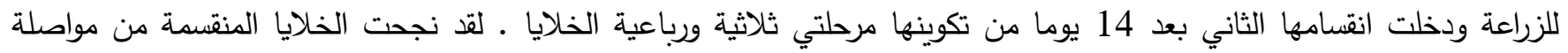

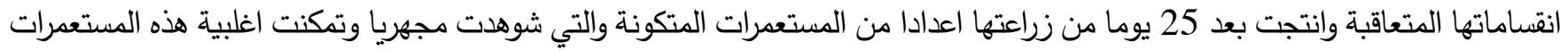

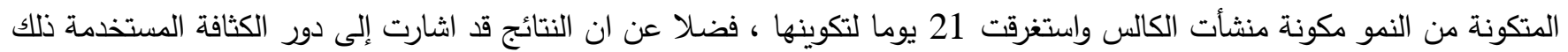

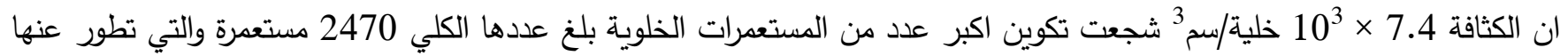

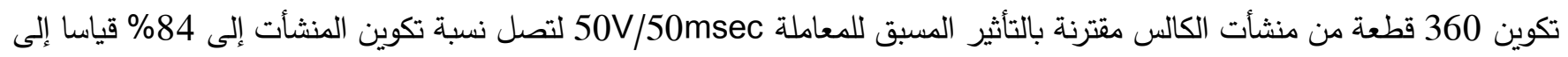
نسبة تكوينها من نظيراتها اذ بلغ العدد الكلي لمنشأت الكالس 88 بادئة أي بنسبة 68\% لعينة المقارنة (الجدول 3) . وقد تمكنت المستعمرات الخلوية المتكونة في معاملة المقارنة من النمو وتكوين منشأت الكالس بعد 90 يوما من زراعتها ـ وامتاز كالسها

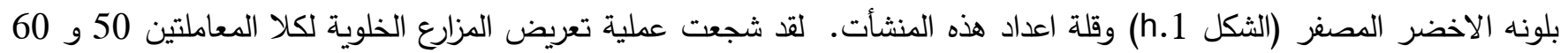

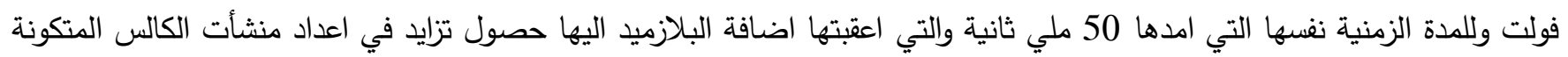

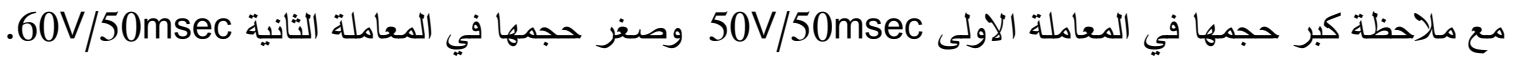
وانفردت المعاملة 50V/100msec في تشجيعها اعداد منشأت الكالس الصغيرة الحجم وعلى نحو مماثل تثابهت كلا المعاملتين

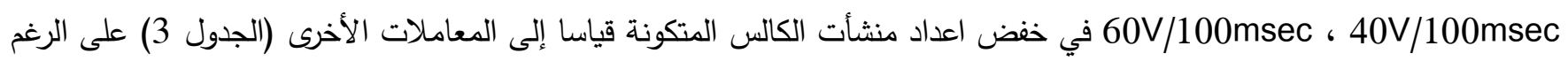

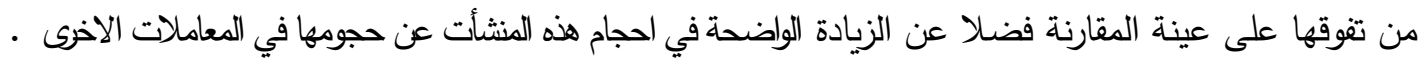

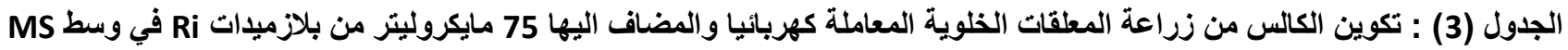

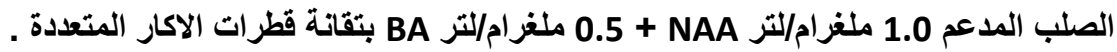

\begin{tabular}{|c|c|c|c|c|c|c|c|c|}
\hline 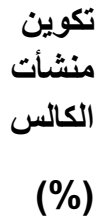 & المنشأت الكاتل العتي & 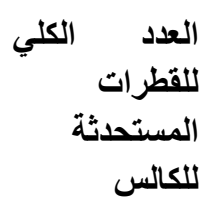 & اللمستعمر ات الكلي & اللقطر ات الكلي & تركيز البلازميد & & كثافة المعلق & المعاملة \\
\hline 68 & 88 & 90 & 100 & 132 & 0 & + & 5.6 & المقارنة (بدون معاملة) \\
\hline 71 & 194 & 85 & 1150 & 120 & 75 & + & 5.9 & $40 \mathrm{~V} / 100 \mathrm{msec}$ \\
\hline 84 & 360 & 114 & 2470 & 135 & 75 & + & 7.4 & $50 \mathrm{~V} / 50 \mathrm{msec}$ \\
\hline 74 & 255 & 75 & 1520 & 102 & 75 & + & 6.3 & $50 \mathrm{~V} / 100 \mathrm{msec}$ \\
\hline 77 & 286 & 87 & 1665 & 113 & 75 & + & 6.8 & $60 \mathrm{~V} / 50 \mathrm{msec}$ \\
\hline 71 & 240 & 94 & 1329 & 132 & 75 & + & 6.0 & $60 \mathrm{~V} / 100 \mathrm{msec}$ \\
\hline
\end{tabular}


القيم الواردة في الجدول تمثل مكررات معدلات اربع مكررات لكل معاملة .

اوضحت نتائج هذه الدراسة امكانية الحصول على مزارع الكالس من السيقان مع التغلب على مجموعة من الصعوبات التي تصاحب

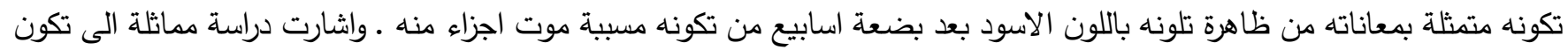

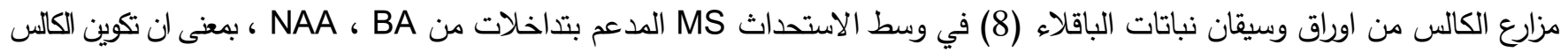

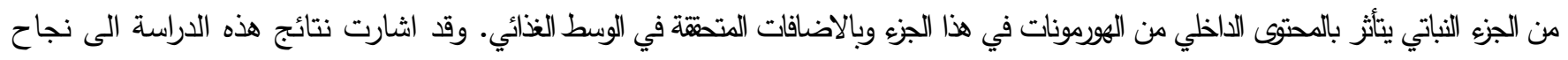

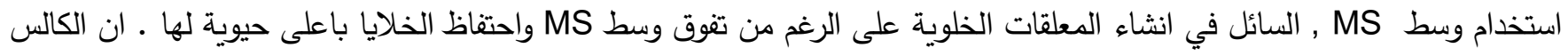

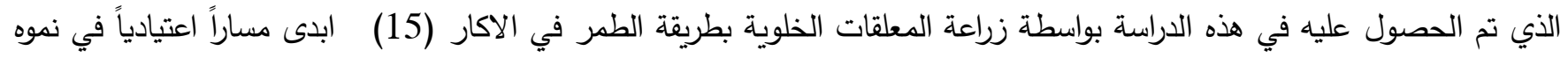

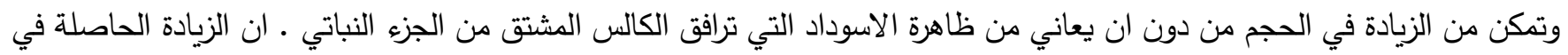

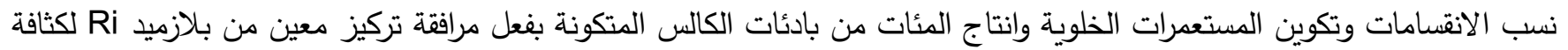

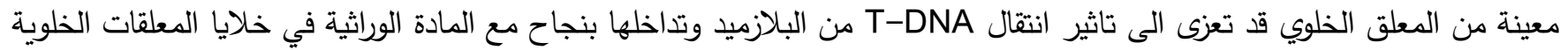
(16) ومن الجدير بالذكر ان عملية انتقال T-DNA من البلازميد Ri الى داخل الخلية النباتية تتم عبر سلسلة من الاحداث تبدأ بالانجذاب

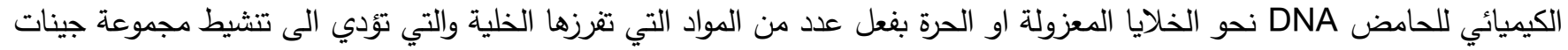

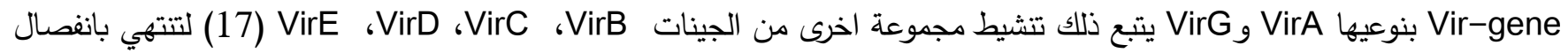

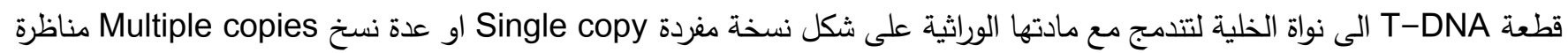
لانقسام الخلية النباتية التي تتواجد فيها (18) ـ ان تقانة الزراعة المرافقة Cocultivation تعد من التقانات الحديثة وتستلزم مزج خلايا

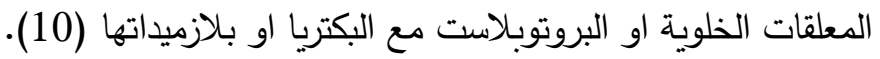

المصادر

1. Das, A.B.; Pattnaik, M.; Thangaraj, T. and Das, P. (1997). Cytophotometric estimation of nuclear DNA content and karyotype analysis of eight cultivars of Trigonella foenum graecum. Cytobio. 91: 171-179.

2. Trinh, T.H.; Ratet, P.; Kondorosi, E.; Durand, P.; Kamate, K.; Bauer, P. and Kondoros (1998). Rapid and efficient transformation of diploid Medicago tranculata and $M$. sativa spp. Falcata lines improved in somatic embryogenesis. Plant Cell Repts., 17: 345-355.

3. Cocking, E.C. and Davey, M.R. (1980). Organogenesis and somatic embryogenesis in tissues derived from leaf protoplasts and leaf explants of Medicago sativa. Z. Pflanzenphysiol. Bd., 99: 261-270.

4. Cocking, E.C. and Davey, M.R. (1988). Electroporation and heat shock stimulate division of protoplasts of Pennisetum squamulatum. Plant Physiol., 133: 547-459.

5. Elibio L.R. Sergio J.O. Pradeep K.C; Michael R.D ; Bernard J.M and John B.P (1988). Electroporation increases DNA synthesis in cultured plant protoplasts. Biotechnology, 6: 1090-1993.

6. Hansen, G. and Wright, M.S. (1999). Recent advance in the transformation of plant. Trends Plant Sci., 4 : 226-231. 


\section{Journal of Education and Science (ISSN 1812-125X), Vol: 30, No: 3, 2021 (225-235) \\ Special Issue for Proceeding of $3^{\text {rd }}$ National (1 $1^{\text {st }}$ international conference of biology) (ICBSUM 2021) 5, 6 July \\ College of Education for Pure Science, University of Mosul, Mosul, Iraq.}

7. Al-Niama, K. Sh. (2013). Electrical fusion between protoplast of two species of Beta vulgaris and interaction of seedling with bacteria GUS-Labelled Gluconacetobacter diazotrophicus GUS gene. PHD thesis Biology Dep. Education collage - Mosul university.

8. Fakhrai, H. and Evans, P.K. (1989). In vitro culture and plant regeneration in Vicia faba subsp. Equina (Var. Spring Blaze). J. Exp. Bot., 40: 813-817.

9. Murashige, T. and Skoog, F. (1962). A revised medium for rapid growth and bioassays with tobacco tissue cultures. Physiol. Plant., 15: 473-497.

10. Zedan S. M. (2004). Cocultivation of callus cell suspension with Ri plasmid for obtaining transformed Broad Bean plant. Ph. D. thesis. university of Mosul, Education Collage Biology Department.

11. Morris, P. and Fowler, M.W. (1981). A new method for the production of fine plant cell suspension culture. Plant Cell, Tiss. and Org. Cult., 1: 15-24.

12. Zedan, S. M. and Rasheed, J. H. (2013). Callus Cultures derived from electrotreated cell suspension of Dianthus caryophyllus L. embedded in ager drops express their totipotency.

13. Brinboim, H.C. and Doly, J. (1979). A rapid alkaline extraction procedure for screening recombinant plasmid DNA. Nucleic Acid Res., 7: 1513-1523.

14. Al-Mallah, M.K. (2002). Invention of electroporator (Al-Jihad 1) and its applications in plant tissue culture. Patent system 3033. Office of standardization and quality control.

15. Dixon, R.A. (1985). Plant Cell Culture, A Practical Approach. IRL. Press. Oxford. U.K.

16. David, C. and Tempe, J. (1988). Genetic transformation of cauliflower (Brassica oleracea L.) by Agrobacterium rhizogenes. Plant Cell Repts., 7: 88-91.

17. Sundberg, C.D. and Rean, W. (1999). The Agrobacterium tumefaciens chaperone-like protein vir E1 interacts with vir E2 at domains required for single-stranded DNA binding and cooperative interaction. J. Bacteriol., 21: 6850 (C.F. Wei et al., 2000).

18. Zambryski, P.C. (1992). Chronicles from the Agrobacterium-plant cell DNA transfer story. Ann. Rev. Plant Physiol. Plant. Mol. Biol., 43: 465 (C.F. (Wei et al., 2000). 